\title{
Parsimonious hydrological modeling of urban sewer and river catchments
}

\author{
Sylvain Coutu*, Dario Del Giudice ${ }^{1,2}$, Luca Rossi, D.A. Barry \\ Laboratoire de technologie écologique, Institut d'ingénierie de l'environnement, Faculté de l'environnement naturel, architectural et construit (ENAC), Station 2, \\ Ecole Polytechnique Fédérale de Lausanne (EPFL), 1015 Lausanne, Switzerland
}

\section{A R T I C L E I N F O}

\section{Article history:}

Received 8 February 2012

Received in revised form 17 July 2012

Accepted 23 July 2012

Available online 1 August 2012

This manuscript was handled by Geoff

Syme, Editor-in-Chief, with the assistance of

Paul Jeffrey, Associate Editor

\section{Keywords:}

Urban hydrology

Modeling

Sewer catchment

Case study

\begin{abstract}
S U M M A R Y
A parsimonious model of flow capable of simulating flow in natural/engineered catchments and at WWTP (Wastewater Treatment Plant) inlets was developed. The model considers three interacting, dynamic storages that account for transfer of water within the system. One storage describes the "flashy" response of impervious surfaces, another pervious areas and finally one storage describes subsurface flow. The sewerage pipe network is considered as an impervious surface and is thus included in the impervious surface storage. In addition, the model assumes that water discharged from several CSOs (combined sewer overflows) can be accounted for using a single, characteristic CSO. The model was calibrated on, and validated for, the Vidy Bay WWTP, which receives effluent from Lausanne, Switzerland (population about 200,000), as well as for an overlapping urban river basin. The results indicate that a relatively simple approach is suitable for predicting the responses of interacting engineered and natural hydrosystems.
\end{abstract}

() 2012 Elsevier B.V. All rights reserved.

\section{Introduction}

Catchment modeling is a mature discipline, and much research and modeling has been carried out on natural catchments. Likewise, urban hydrological modeling has now reached a state of maturity in terms of prediction of the hydrologic response of urban or partially urbanized basins (Delleur, 2003; Ashley et al., 1999; Borah, 2011). As discussed in detail by Zoppou (2001), urban stormwater models are based on detailed spatial descriptions of the constituent drainage networks. Such models are valuable for many purposes, of course.

Most popular urban hydrological models used in research and engineering (e.g., MOUSE (Hernebring et al., 2002), SWMM ${ }^{3}$ ) are spatially distributed with link-node drainage networks. Detailed modeling of drainage systems is often deemed necessary because of the complexity of flow paths in urban catchments (Cantone and Schmid, 2011; Gironás et al., 2009). Yet, water science abounds with mathematical tools designed for lumped hydrological studies, including stochastic and deterministic approaches (see, e.g., Singh

\footnotetext{
* Corresponding author. Tel.: +41 (0)21 6938024.

E-mail address: sylvain.coutu@epfl.ch (S. Coutu).

1 Present address: Eawag, Swiss Federal Institute for Aquatic Science and Technology, Ueberlandstrasse 133, CH-8600 Duebendorf, Switzerland.

2 Address: Institute of Environmental Engineering, Swiss Federal Institute of Technology Zürich (ETHZ), 8093 Zürich, Switzerland.

3 http://www.epa.gov/nrmrl/wswrd/wq/models/swmm/, last accessed December 2011.
}

and Woolhiser (2002) for a review). But, so far, these models have been mostly tested on rural areas where a parsimonious approach is more evident (Amin and Campana, 1996; Beven and Kirkby, 1979; Jacobson, 2011; Kelman, 1980; Perrin et al., 2001; Yadav et al., 2007).

Here, we explore a simplified approach to urban hydrology modeling based on a lumped approach, as an alternative to detailed network modeling. Lumped models are appropriate when the focus of the modeling effort is the catchment outlet, which is the case considered here. The model integrates the main physical processes in urban catchments (i.e., precipitation, infiltration, soil moisture, runoff, streamflow and groundwater flow), but without consideration of the detailed pipe drainage network. The model is designed to predict the flow (i) at the entrance of a WWTP (Wastewater Treatment Plant), which is the endpoint of the city's drainage system, and (ii) in an engineered urban river basin, which also receives flow from the city. In urban systems, these two endpoints drain overlapping basins.

The model is based on a small number of storages that account for the main features of an urban catchment, i.e., (i) high proportion of impervious surfaces, (ii) complex drainage system, (iii) presence of CSOs (combined sewer overflows), and (iv) artificial water inputs. In addition, the hydrological model integrates functions that aim to reproduce characteristic daily variations of dry weather flow to the WWTP. The model is validated for a WWTP drainage basin and for an urban river. The two considered basins partly overlap over the city of Lausanne, Switzerland. 


\section{Design and mathematical description of the model}

The basin is modeled as a set of three storages (one surface and two subsurface), each characterized by a state variable representing the water stored within it (Fig. 1). The two meteorological forcings considered are precipitation and air temperature, $\mathscr{T}$, both assumed uniform over the basin. The type of precipitation is determined based on a temperature threshold (DeWalle and Rango, 2008; Schaefli et al., 2005): when $\mathscr{T}$ is above the threshold $\mathscr{T} \mathrm{cr}$, precipitation occurs as rain, otherwise precipitation is frozen.

The water is considered to flow on surfaces and in the subsurface (c.f., Kirkby, 1988; Musy and Higy, 2010; Quinn et al., 1991; Rinaldo et al., 2006; Rodriguez-Iturbe and Valdes, 1979). The surface compartment, responsible for surface runoff, is modeled as a fast-reacting (transient) storage characterized by a water volume of $S_{s}$ cf.(Beven and Kirkby, 1979; Fenicia et al., 2007; Puente et al., 1993; Todini, 1988). The subterranean layer is represented as composed of two reservoirs: the upper soil (or root zone) region and the groundwater region with, respectively, storages of $S_{u}$ and $S_{g}$ (Botter et al., 2010). $S_{s}$ and $S_{g}$ are considered to extend over the total surface of the catchment, whereas $S_{u}$ occupies only the pervious fraction of the basin (Fig. 1).

\subsection{Modeling of surface processes}

In urban basins, the rapid run-off response to precipitation is an important feature (Basu et al., 2010; Deletic, 1998; Elliott and Trowsdale, 2007; Gupta and Saul, 1996; Jacobson, 2011). This water bypasses the subsurface flow, and is treated as a separate component in the lumped model. Physically speaking, this amounts to dividing the catchment area into pervious and impervious surfaces, with the latter producing the rapid runoff component.

The flux of precipitation falling on each part is, respectively, $j A_{p}$ and $j A_{i}$, where $A_{p}$ and $A_{i}\left[L^{2}\right]$ represent the permeable and impermeable areas (Fig. 1 ) and $j\left[L T^{-1}\right]$ is the precipitation rate. Note that, for an urban basin equipped with a partially-separated sewer system, $A_{i}$ comprises the fraction of the impermeable area actually contributing to the discharge.

When falling on the pervious fraction of the basin, the rain can either infiltrate or produce overland flow. The infiltration flux, $I$ $\left[L^{3} T^{-1}\right]$, is described by a simplified law derived from the Horton function (e.g., Hingray et al., 2009; Horton, 1940; Ravi and Williams, 1998):
$I=A_{p} \times \operatorname{Min}\left[j, K_{\text {sat }}\left(10-9 \frac{\theta}{n}\right)\right]$,

where $K_{\text {sat }}\left[L T^{-1}\right]$ is the saturated hydraulic conductivity, $\theta[-]$ the soil moisture content and $n[-]$ the effective porosity.

When the precipitation exceeds the soil infiltration capacity, the surplus precipitation becomes infiltration-excess overland flow (Beven, 2004; Cundy and Tento, 1985; Engman and Rogowski, 1974; Evans et al., 1999). In this circumstance, the compartment to which the infiltration flux is directed is not saturated when runoff occurs. In the model, the excess precipitation is transferred to a surface storage. This storage also receives the precipitation flux falling on any impervious surfaces, $j A_{i}$. The output, $Q_{\text {sup }}$, from this storage produces the fast component of the total streamflow. The water-budget equation for the surface storage is:

$\frac{d S_{s}(t)}{d t}=R(t)+A_{i} j(t)-Q_{\text {sup }}(t)$,

where $R=j A_{p}-I, Q_{\text {sup }}=k_{\text {sup }} S_{s}$ and $k_{\text {sup }}$ is the rate discharge of the impervious surface linear reservoir. When Hortonian infiltration is exceeded (Eq. (1)), a fraction $R$ of the rainwater is added to the overland flow.

\subsection{Modeling of subsurface processes}

Surface infiltration enters the root zone storage, the total volume of which is:

$S_{u}=Z \theta A_{p}$,

with $Z[L]$ the depth of the active soil layer. Two types of outputs from this region are considered: evapotranspiration, ET, and deep percolation, $J_{e}$. The water vapor flux is modeled as:

$E T=A_{p} E T_{\max } f(\theta)$,

where $E T_{\max }\left[L T^{-1}\right]$ is the maximum (potential) flux of water that can be lost as vapor and $f(\theta)$ represents the restriction on water extraction due to the soil's moisture content:

$$
f(\theta)= \begin{cases}0, & \theta<\theta_{w}, \\ \frac{\theta-\theta_{w}}{\theta^{*}-\theta_{w}}, & \theta_{w} \leqslant \theta \leqslant \theta^{*}, \\ 1, & \theta^{*}<\theta<n,\end{cases}
$$

where $\theta_{w}$ is the permanent wilting point and $\theta^{*}$ the critical soil moisture level at which the plant begins to close stomata in response to water stress (e.g., Dingman, 1994; Nicótina et al., 2011;

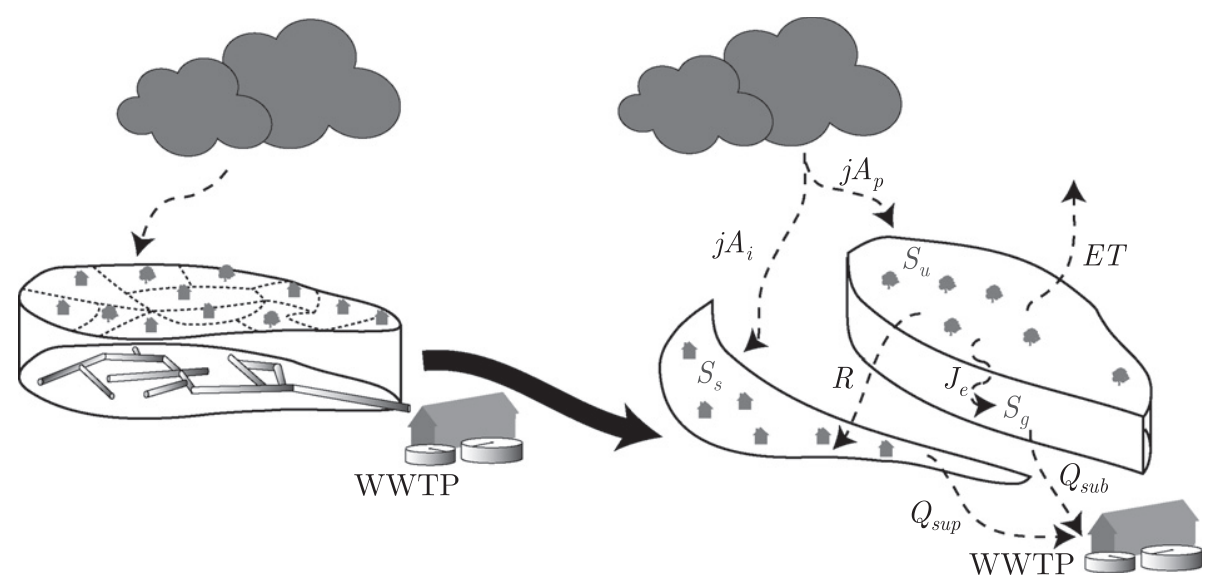

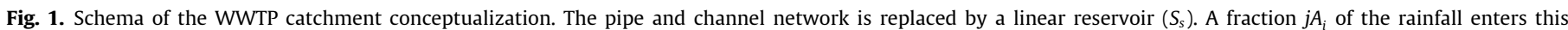

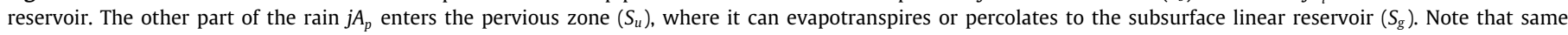

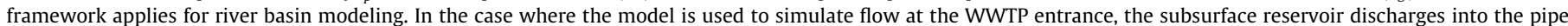

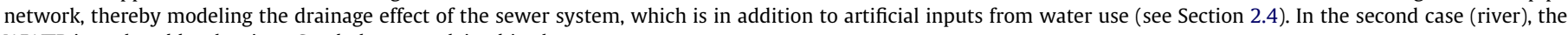
WWTP is replaced by the river. Symbols are explained in the text. 
Rodrìguez-Iturbe and Porporato, 2005). The dryness state is assumed to be reached when the relative soil water content is below $65 \%$ (i.e., $\theta^{*} \approx 0.65 n$ ) (cf., Nicótina et al., 2011).

The maximum evapotranspiration is computed through a modified version of the Blaney-Criddle equation (e.g., Doorenbos and Pruitt, 1975):

$E T_{\max }=a+b[p(0.46 \mathscr{T}+8.13)]$,

where $a$ and $b$ are fitting parameters and $p$ is the mean annual percentage of daytime hours, which varies only with latitude (Allen et al., 1998).

The second loss from the upper soil region is due to percolation to groundwater. According to a widely used parameterization of vertical gravity-driven flow (e.g., Botter et al., 2010; RodrìguezIturbe and Porporato, 2005), the leaching from the root zone is computed as:

$J_{e}=A_{p} K_{\text {sat }}\left(\frac{\theta}{n}\right)^{c}$.

The deepest subterranean region is modeled as a linear reservoir recharged by the leaching from the upper soil layer. The water flux from this zone, $Q_{\text {sub }}=k_{\text {sub }} S_{\mathrm{g}}$, is used to simulate the baseflow in the river, when this model is applied to the natural region. For application to the sewer catchment, the subterranean flow represents the transfer of water from soil to the drainage system. Indeed, a non-negligible part of the infiltrated water can be drained by the pipe network, principally depending on soil characteristics (Berthier et al., 2004; Karpf and Krebs, 2011). This infiltration of groundwater to the drainage network must in consequence be considered in the water dynamics (Dupont et al., 2006; Göbel et al., 2004).

The mass conservation equations modeling near-surface and deep soil water dynamics are:

$$
\begin{aligned}
& \frac{d S_{u}(t)}{d t}=I(t)-E T(t)-J_{e}(t), \\
& \frac{d S_{g}(t)}{d t}=J_{e}(t)-Q_{s u b}(t) .
\end{aligned}
$$

This formulation of subterranean flow, based on Botter et al. (2010), is easily extendible to account for interflow (or subsurface runoff) through shallow soil layers. This "fast internal flow", with drainage capacity in between overland and deep flow, could be a relevant component of hydrographic recession curves for anisotropic soils in which the lateral hydraulic conductivity dominates that in the vertical (Hingray et al., 2009; Musy, 2005; Raghunath, 2006; Shaw,

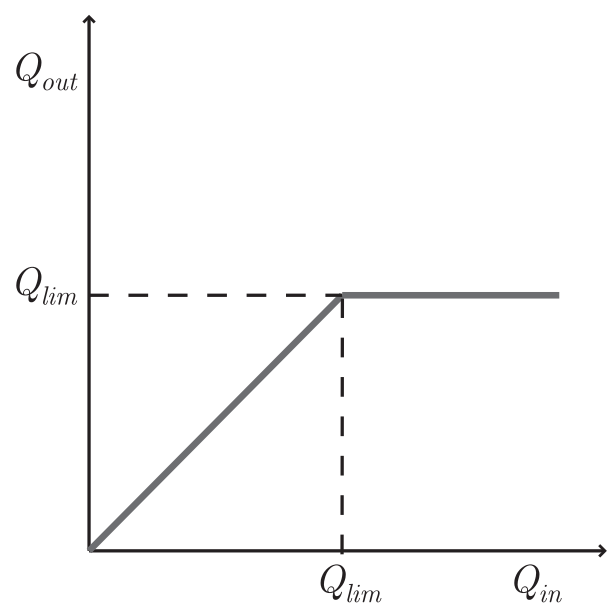

Fig. 2. Linear low partitioning function applied to the representative CSO. The maximum flow reaching the WWTP is limited by the threshold, $Q_{\text {lim }}$. The excess is diverted out of the modeled pipe network.
Table 1

Mathematical expressions of adopted fitting criteria functions e.g.,(Nash and Sutcliffe, 1970; Hingray et al., 2009; Schaefli and Gupta, 2007; Fenicia et al., 2007; Reusser et al., 2008). $Z_{\text {sim }}$ and $Z_{\text {obs }}$ are the modeled and observed values and $n$ is the number of observations.

\begin{tabular}{lll}
\hline Criterion function & Expression & Optimal value \\
\hline Nash-Sutcliffe & $1-\frac{\sum_{i=1}^{n}\left[Z_{\text {obs }}(i)-Z_{\text {sim }}(i)\right]^{2}}{\sum_{i=1}^{n}\left[Z_{\text {obs }}(i)-\bar{Z}_{\text {obs }}\right]^{2}}$ & 1 \\
Normalized Bias & $\frac{\sum_{i=1}^{n}\left[Z_{o b b}(i)-Z_{\text {sim }}(i)\right]}{n \bar{Z}_{\text {obs }}}$ & 0 \\
\hline
\end{tabular}

Table 2

Calibration parameters and the range of values considered. For the Monte-Carlo parameter optimization procedure, a uniform distribution was considered.

\begin{tabular}{llll}
\hline Parameter & Symbol & Lower bound & Upper bound \\
\hline Saturated conductivity & $K_{\text {sat }}\left(\mathrm{m} \mathrm{s}^{-1}\right)$ & $1.4 \times 10^{-6}$ & $2.6 \times 10^{-5}$ \\
Wilting point & $\theta_{w}$ & 0.14 & 0.26 \\
Clapp exponent & $c$ & 1 & 20 \\
ET parameter & $a$ & -4.8 & -0.84 \\
ET parameter & $b$ & 0.7 & 1.19 \\
Subsurface discharge rate & $k_{\text {sub }}\left(\mathrm{s}^{-1}\right)$ & $2.8 \times 10^{-8}$ & $3.8 \times 10^{-7}$ \\
Surface discharge rate & $k_{\text {sup }}\left(\mathrm{s}^{-1}\right)$ & $2.0 \times 10^{-5}$ & $3.8 \times 10^{-4}$ \\
\hline
\end{tabular}

1994). In this case, the hydrological model proposed can be enhanced by limiting the deep percolation reaching the groundwater storage and diverting part of it into streamflow (cf., Thomet, 2010).

\subsection{Consideration of CSOs}

A characteristic feature of hybrid sewer networks are CSOs. In the drainage network, CSOs divert flows above a certain level directly to receiving waters, rather than to the WWTP (Butler and Davies, 2010; Lee and Bang, 2000; Wisner et al., 1981). Although a sewer network usually consists in several CSOs, we consider in this study that a single, representative flow delimiter is sufficient to model the effect of all CSOs of the system in a lumped fashion manner. This representative CSO is modeled using a diversion law that follows a linear threshold-limited function (in Fig. 2).

\subsection{Dynamics of wastewater production}

During dry weather, discharges arriving at the WWTP inlet are determined mainly by two phenomena: (i) infiltration of groundwater into the pipe network (see Section 2.2 and Dupont et al. (2006); Göbel et al. (2004)) and, (ii) water use and consequent wastewater production. This 'artificial' water input, which is not present in a natural catchment, is modeled based on statistical analysis presented by Jordan (2010). In this study, monthly, daily and hourly flow coefficients are extrapolated from temporal series analysis and considered as characteristic of the system. This includes direct water consumption in households, and all parasitic clear water (fountains, street washing, industrial uses, etc).

\section{Optimization of hydrological quality index}

Model calibration was performed based on the two objective functions in Table 1, since this combination has been found to yield better overall fits (Hingray et al., 2009; Perrin et al., 2001). The list of fitting criteria and the range of prior values given before calibration process can be found in Table 2 .

Similarly to Fenicia et al. (2006) and Seibert (2000), the calibration approach adopted here is based on a Monte Carlo algorithm designed to optimize the model performance, using the 


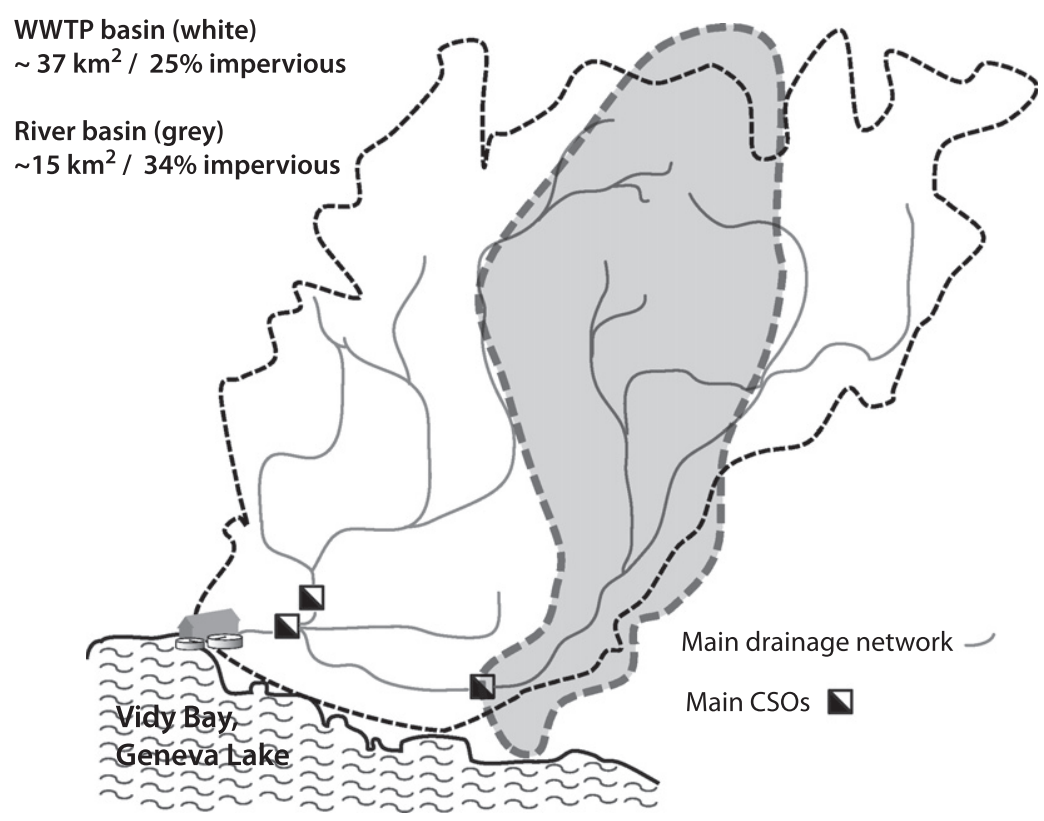

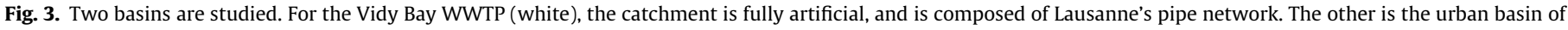
the Vuachère river (gray). The two basins partly overlap.

Nash-Sutcliffe (NS) and the Normalized Bias (NB) criteria (Table 1). The former places an emphasis on the model's ability to estimate large magnitudes (i.e., peak discharge), while the latter weights more the deviation between simulated and observed water balance, as follows:

$\operatorname{Min}\{(1-N S)+|N B|\}$.

\section{Case study and results}

4.1. Application of the model to an urban basin: Modeling of flow at the river outlet and WWTP entrance

The same modeling framework is employed to model both the dynamics of flows at an urban river outlet and inlet of a local WWTP. The application area is the city of Lausanne in Switzerland, which has a population of about 200,000 and is characterized by a steep average gradient towards nearby Lake Geneva. A feature of Lausanne is that the WWTP catchment and the river catchment overlap over a fraction of the city (Fig. 3). The model is calibrated twice on the same time period, once to model the WWTP input, and once to model the river output to the adjacent Lake Geneva, which is the receiving water body for both river and WWTP discharges.

\subsection{Application to the WWTP basin}

The WWTP catchment under study is the Lausanne hybrid (partially-separate) sewer system, drains to the Vidy Bay WWTP. It is a typical urban catchment, where much water comes from toilets, washing, industry and other uses, rather than directly from natural sources. The channels comprising the WWTP basin consist mainly of concrete galleries, pipes and overflows, which often do not follow the natural topography and sometimes even move upslope, driven by pumping stations (Assainissement Lausanne, 2009).

The Vidy Bay WWTP treats about $6 \times 10^{4} \mathrm{~m}^{3}$ of wastewater daily. Flow data were collected at the entrance of the WWTP (Jeanbourquin et al., 2011; Nguyen et al., 2009). Rain and temperature information were extracted from a nearby meteorological station managed by the Swiss Federal Office of Meteorology and Climatology. 4

There is significant heterogeneity in the WWTP basin: The oldest, central part of the catchment is made up of a combined sewer system, in which wastewater and stormwater flow together, whereas in newer, surrounding areas, separate drainage systems have been installed (i.e., wastewater and stormwater are collected separately). The combined system drains about $30 \%$ of the WWTP basin, while its imperviousness is around 25\% (Rossi et al., 2008). Note that $70 \%$ of the WWTP basin consists of separate sewer system. A large part of the water is in consequence diverted through drainage out of the WWTP basin. This fraction of water does not participate in the flow to the WWTP entrance and was thus removed from the system.

The hydrological model setup for the WWTP basin was calibrated over the period July-November 2010. The comparison of observed and computed hydrographs is satisfactory (Fig. 4), with a NS coefficient of 0.73 and NB of 0.00041 . Good performance was achieved also for the validation period November 2010-January 2011, as can be seen in Fig. 4, with fitting metrics in the same range.

The model reproduces well dry weather conditions as well as peak discharges. In this case, the flow rate at the WWTP entrance during significant storm events is attenuated by the presence of CSOs; this behavior is captured by the simulator. As stated above, all CSO's in the network are represented by a single CSO and diversion law (Section 2.3), for which a single parameter, $Q_{\text {lim }}$, must be selected. For the latter, we used the $Q_{\lim }$ value for the CSO at which most diversion occurs. This CSO, the closest CSO to the WWTP, is responsible for more than a third of all CSO discharge, and is typically the first to become operational in storms (e-dric.ch, 2008).

The modeling results in Fig. 4 do not capture perfectly the measured data. Such differences could arise from the inherent stochastic nature of wastewater production (Rieckermann et al., 2011) or measurement errors at the WWTP. In addition, rainfall measurements from a single location were used, without any consideration of possible spatial variations due, for example, to topographic

\footnotetext{
${ }^{4}$ http://www.meteosuisse.ch, last accessed January 2012.
} 
(a)
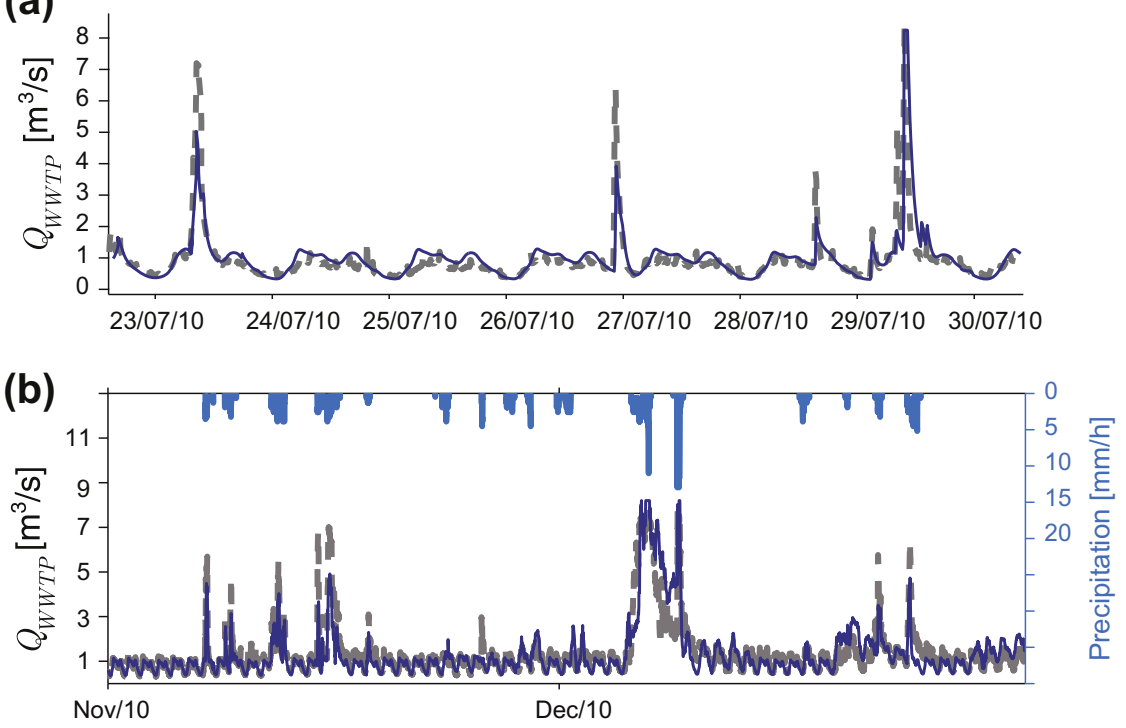

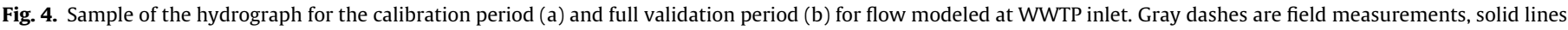
are model predictions and precipitation rate is on the right abscissa of (b).

effects (Huff and Vogel, 1978; Kieffer and Bois, 2001). Nevertheless, the fitting metrics used confirm the overall satisfactory predictive power of the model $(\mathrm{NS}=0.73, \mathrm{NB}=0.0041$ ).

The described modeling approach was also compared with the distributed model RS-3.0 used by the local authorities to manage flow the WWTP inlet. This model is a SWMM-type object-oriented program developed in the VBA environment (Dubois and Boillat, 2000). The model simulates Lausanne's full routing network (100 sub-basins, 12 CSOs and 2 pumping stations), with flow based on the kinematic wave approximation.

As shown by Fig. 5, the two models closely agree during dry weather. The lumped model results are somewhat smoother. The dry weather flow variations at WWTP inlet follow monthly, daily and hourly variations around the mean base flow. These variations in our model have been described by assigning to the base flow corresponding coefficients (monthly, daily, hourly). These coefficients are taken from local public wastewater management reports (Assainissement Lausanne (2009)). During rain events, the magnitude of the simulated peaks correspond for the two models, although we observe a faster response time for the lumped model. Structural differences between the two models are so numerous that it would be difficult to isolate a specific reason to explain this. First, slope effects can explain the velocity of the response, but basin slope is not directly involved in our model, even if slope is indirectly integrated into reservoir discharge rate. Volumes simulated during the rain events are in the same range $\left(11.1 \times 10^{4} \mathrm{~m}^{3}\right.$ for RS-3.0 and $9.6 \times 10^{4} \mathrm{~m}^{3}$ for the lumped model). The difference in the distribution of pervious/impervious areas between the two models could also explain the shift. Our model considers a uniform distribution whereas RS-3.0 uses different distributions for the 100 sub-basins that are routed together. Globally, the results in Fig. 5 show satisfactory agreement.

\subsection{Application to the river basin}

The modeled river, called the Vuachère, is located in the eastern part of the city of Lausanne (Fig. 3). The total area of the catchment is about $15 \mathrm{~km}^{2}$, of which approximately $34 \%$ is impervious. According to data shown by Jordan (2010), about $60 \%$ of the runoff generated on the Vuachère's impervious surfaces contributes to the river discharge, while the rest is considered to flow into the sewer system.

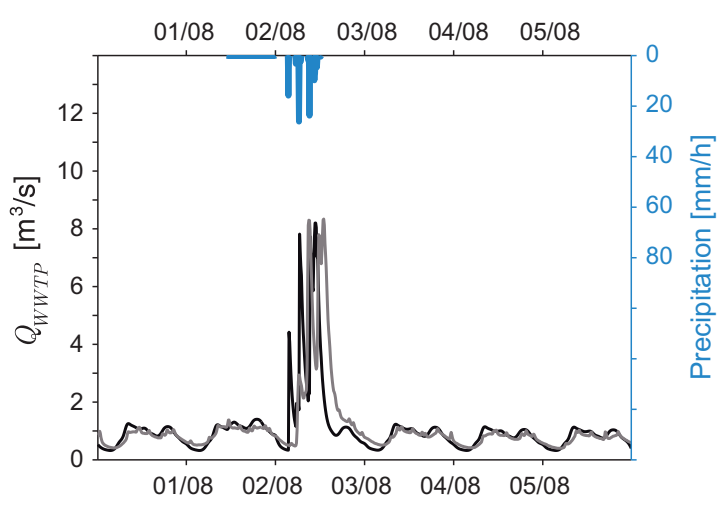

Fig. 5. Comparison of flow modeled at the WWTP with the presented model (black) and the RS-3.0 model (gray).

The flow rate was measured at the outlet of the river basin, just before discharge into Lake Geneva. The calibration and validation periods were taken the same as for the WWTP basin modeling. Close agreement is shown in the comparison of predicted and measured flow rates (Fig. 6).

Different factors in the model drive the simulated flow dynamics in the river. The subsurface reservoir discharge constant controls the river's base flow. The magnitude of peak discharge during rain events is controlled by the impervious surface reservoir area. The volume of water involved in the fast response of the basin during rainfall, on the other hand, is driven by three factors: (i) the fraction of impervious area of the basin, (ii) the fraction of water diverted to the WWTP through the pipe network due to the presence of CSOs, and (iii) infiltration excess (when the rainfall intensity exceeds the infiltration rate limit, the excess is diverted to the impervious reservoir, and is thus transported rapidly to the river).

\section{Sensitivity analysis}

A sensitivity analysis was conducted to estimate the influence of the model parameters (Table 2). Each parameter was varied within the prior range of acceptable values for this parameter, and the two fitting criteria (Nash-Sutcliff and Normal Bias) computed. Results are presented in Fig. 7. 

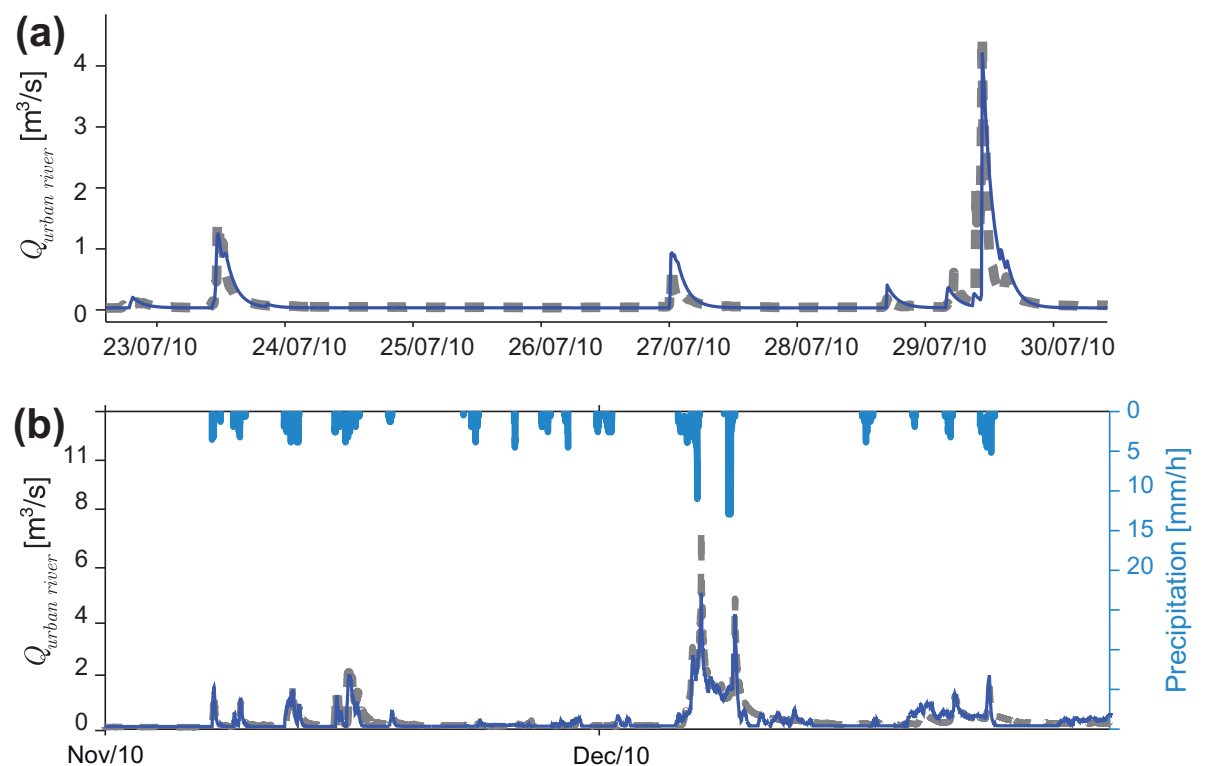

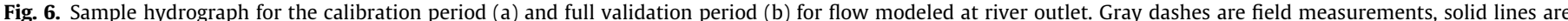
model predictions and precipitation rate is on the right abscissa of (b).
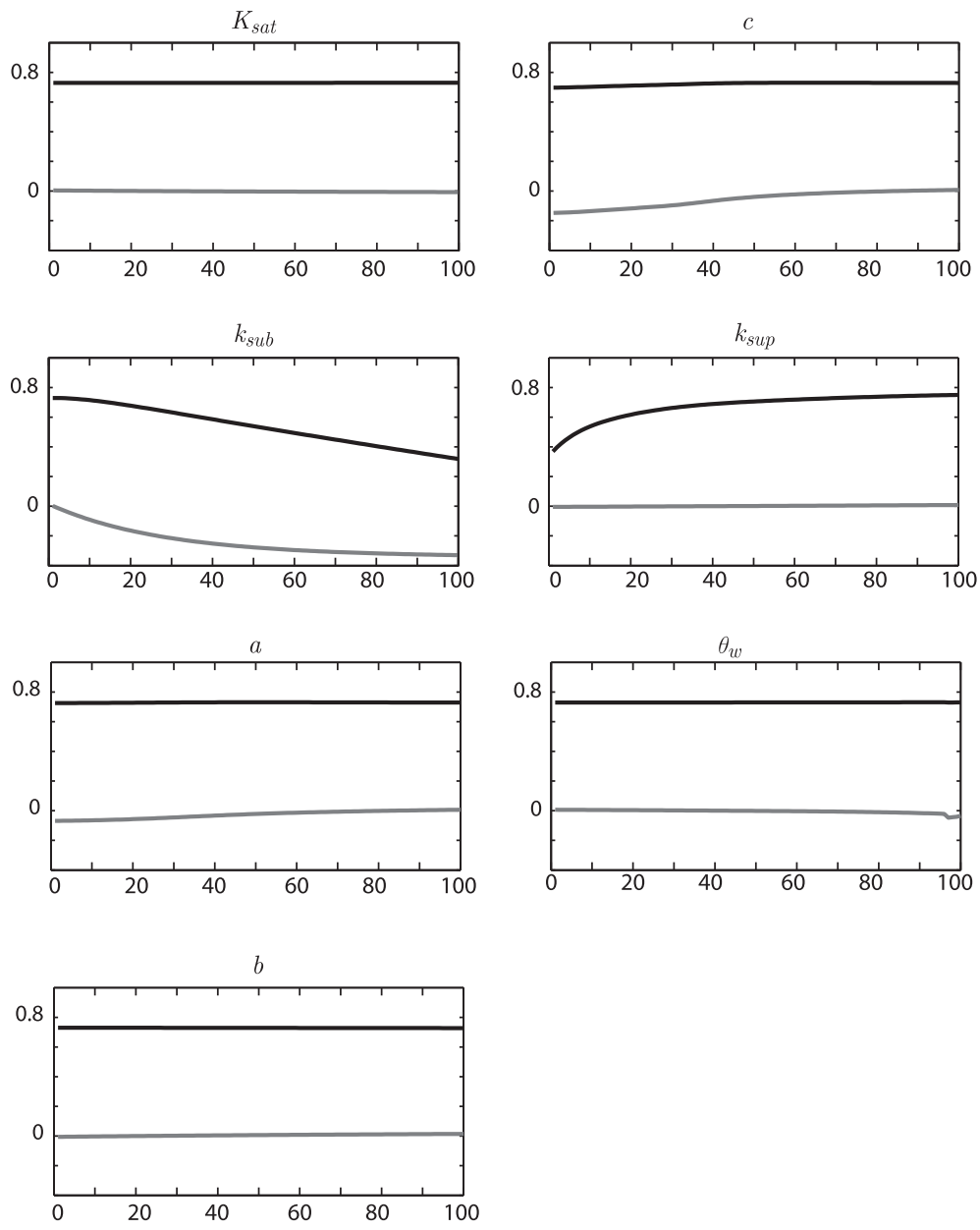

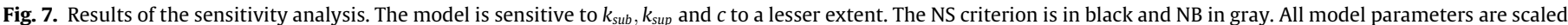
between 0 and 100 . 


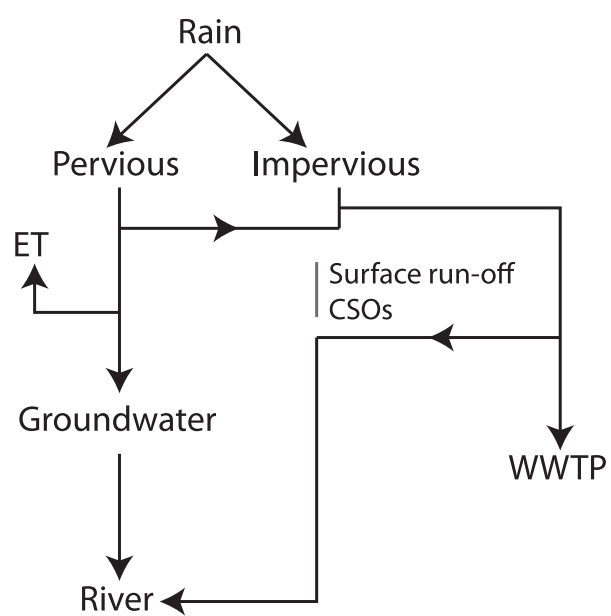

Fig. 8. Dominant pathways considered. Endpoints of the system are the river and the WWTP.

We see from Fig. 7 that two parameters mainly govern the overall performance of the model. These are the discharge constants of the surface impervious reservoir $\left(k_{\text {sup }}\right)$ and the subsurface reservoir $\left(k_{\text {sub }}\right)$. Note that $k_{\text {sup }}$ affects the flashy response of rainfall on the impervious surface. The Nash-Sutcliff criterion is particularly sensitive to variations of this parameter. On the other hand, changes in the $k_{\text {sub }}$ value degrade the ability of the model to reproduce the base flow, and thus move the Normal Bias criterion away from its optimal value of 0 , in addition to affecting the Nash-Sutcliff criterion. The values of other calibration parameters within the prior range of selected possible values affect only minimally the quality of model predictions.

\section{Discussion}

The lumped modeling approach was designed to predict, with an identical framework, both flow at the WWTP inlet and at the outlet of the river basin overlapping the WWTP catchment. The approach is consistent with the main physical processes responsible for water transfer at basin scale. The dominant physical processes driving water discharge at the two basin end-points in this study are Hortonian runoff, evapotranspiration, and gravity-driven percolation to groundwater. Saturation excess was not implemented in our modeling scheme as we considered an unlimited reservoir height - i.e., the reservoir is never full - and this could lead to underestimation of surface runoff (Buda et al., 2009; MartínezMena et al., 1998; Nachabe et al., 1997). Saturation excess could be easily implemented but at cost of additional calibration parameter. Run-off from impervious surfaces and groundwater discharge are modeled as responses of linear reservoirs. This choice allows us to keep the same parsimonious approach for the modeling of both the rural and urban basins. In facts, several studies suggest that the transfer function of an urban basin is not unique, the complexity of the different pathways leading to deviations from the Horton law in a certain extent (Berthier et al., 1999; Rodriguez et al., 2003, 2005). Despite structural heterogeneities that are inherent in urban areas, the simplified model adopted here captures flow variations in both the river and sewer network.

Fig. 8 shows the routes by which the proposed framework transmits water to the catchment end-points (i.e., WWTP inlet or river outlet). A major assumption is that the pipe network is considered as a part of the impervious surface. In other words, no distinction is made between overland and "underground" runoff, as both are characteristics of engineered basins. "Underground" runoff results from an underground impervious area - the pipe net- work - that increases the intensity of the "flashy" response of the basin, as more water is diverted quickly to the end-point of the system.

Another key assumption is the way CSOs are represented. For the river, CSOs provide additional water as excess water in the pipe network is diverted to prevent overloading the WWTP. Thus, CSOs act as point sources of water for the urban river, and point drains for the WWTP basin. As explained in Section 2.3, only the hydraulic function of the most representative CSO was considered. This simplification was found to be reasonable as predicted results match field measurements and simulations from the current distributed model (RS-3.0, using 12 separate CSOs) used by Lausanne authorities for WWTP flow management. For the WWTP catchment, the final CSO was found to be the most influential, and indeed controlled the CSO contribution to the WWTP. This occurred for two reasons: (i) it is the first CSO to discharge water when rain occurs and, (ii) it is the last CSO before our flow measurement point (WWTP inlet).

Cantone and Schmidt (2009) discussed the potential problems that could arise in simplifying sewer hydrologic/hydraulic models, and concluded that to lump together interacting nonlinear processes of the system could affect the outfall hydrograph. However, inclusion of elements of the system can lead to over-parameterization of the system and increase uncertainties as discussed by Leon et al. (2010). In agreement with Leon et al. (2010), the study presented here presents a physically consistent model that, despite its simplifications, allows prediction of water flow dynamics in two structurally different basins.

\section{Conclusion}

In this study, a hierarchical physically based storage and transmission model was designed as an alternative means for simulating continuous flow dynamics in complex engineered urban basins. The model ignores the complexity of the drainage network, while reproducing efficiently the flow dynamics at the different end-points. Two important modeling assumptions are: (i) the pipe network is replaced by an underground impervious area and thus overland flow and pipe discharge can be together modeled as a fast discharge linear reservoir, and (ii) the water diverted out of the sewer system through the different CSOs can be combined together through the hydraulic discharge function of a representative CSO.

Putting aside the drainage network complexity leads to a large decrease in both the number of model parameters and computation time. Therefore, our approach is ideal for repetitive tasks such as model calibration and optimization. In addition, the model can serve as the flow part of more complex models assessing complex diffuse pollution production and transfer processes. We suggest that the model has potential as a tool for WWTP management and urban water resource planning.

\section{References}

Allen, R.G., Pereira, L.S., Raes, D., Smith, M., 1998. Crop evapotranspiration. Guidelines for computing crop water requirements. Technical Report. FAO Irrigation and Drainage Paper (FAO), Rome.

Amin, I.E., Campana, M.E., 1996. A general lumped parameter model for the interpretation of tracer data and transit time calculation in hydrologic systems. J. Hydrol. 179, 1-21.

Ashley, R.M., Hvitved-Jacobsen, T., Bertrand-Krajewski, J., 1999. Quo vadis sewer process modelling? Water Sci. Technol. 39, 9-22.

Assainissement Lausanne, 2009. Plans généraux d'évacuation des eaux - cadastre des canalisations. Technical Report. Ville de Lausanne. <http:// www.lausanne.ch/assainissement> (accessed 01.12).

Basu, N.B., Rao, P.S.C., Winzeler, H.E., Kumar, S., Owens, P., Merwade, V., 2010. Parsimonious modeling of hydrologic responses in engineered watersheds: structural heterogeneity versus functional homogeneity. Water Resour. Res. 46, W04501. 
Berthier, E., Andrieu, H., Creutin, J.D., 2004. The role of soil in the generation of urban runoff: Development and evaluation of a 2D model. J. Hydrol. 299, 252-266.

Berthier, E., Andrieu, H., Rodriguez, F., 1999. The Rezé urban catchment database. Water Resour. Res. 35, 1915-1927.

Beven, K.J., 2004. Rainfall-Runoff Modelling: The Primer. John Wiley \& Sons Ltd., Chichester, UK.

Beven, K.J., Kirkby, M.J., 1979. Physically based, variable contributing area model of basin hydrology. Hydrol. Sci. Bull. 24, 43-69.

Borah, D.K., 2011. Hydrologic procedures of storm event watershed models: A comprehensive review and comparison. Hydrol. Processes 25, 3472-3489.

Botter, G., Bertuzzo, E., Rinaldo, A., 2010. Transport in the hydrologic response: travel time distributions, soil moisture dynamics, and the old water paradox. Water Resour. Res. 46, W03514.

Buda, A.R., Kleinman, P.J.A., Srinivasan, M.S., Bryant, R.B., Feyereisen, G.W., 2009. Factors influencing surface runoff generation from two agricultural hillslopes in central Pennsylvania. Hydrol. Processes 23, 1295-1312.

Butler, D., Davies, J., 2010. Urban Drainage, third ed. Spon Press, London, UK

Cantone, J.P., Schmid, P., 2011. Improved understanding and prediction of the hydrologic response of highly urbanized catchments through development of the Illinois Urbana Hydrologic Model. Water Resour. Res. 47, W08538.

Cantone, J.P., Schmidt, A.R., 2009. Potential dangers of simplifying combined sewer hydrologic hydraulic models. J. Hydrol. Eng. 14, 596-605.

Cundy, T.W., Tento, S.W., 1985. Solution to the kinematic wave approach to overland flow routing with rainfall excess given by Philip's equation. Water Resour. Res. 21, 1132-1140.

Deletic, A., 1998. The first flush load of urban surface runoff. Water Res. 32, 24622470.

Delleur, J.W., 2003. The evolution of urban hydrology: Past, present, and future. J. Hydraul. Eng.-ASCE 129, 563-573.

DeWalle, D.R., Rango, A., 2008. Principles of Snow Hydrology. Cambridge University Press.

Dingman, S., 1994. Physical Hydrology. Macmillian, New York.

Doorenbos, J., Pruitt, W.O., 1975. Guidelines for predicting crop water requirements. Technical Report. Irrigation and Drainage Paper (FAO) Rome. ISBN: 9251002797.

Dubois, J., Boillat, J., 2000. Routing System - Modélisation du routage des crues dans des systèmes hydrauliques à surface libre. Communications du Laboratoire de constructions hydrauliques 9. EPFL/LCH. <http://infoscience.epfl.ch/record/ 116157> (accessed 01.12)

Dupont, S., Mestayer, P.G., Guilloteau, E., Berthier, E., Andrieu, H., 2006. Parameterization of the urban water budget with the submesoscale soil model. J. Appl. Meteorol. Climatol. 45, 624-648.

e-dric.ch, 2008. Réseau d'assainissement de la ville de Lausanne: diagnostic du réseau par modélisation hydraulique. Technical Report. e-dric.ch, ingenieurs conseils. ISSN: 1018-760X

Elliott, A.H., Trowsdale, S.A., 2007. A review of models for low impact urban stormwater drainage. Environ Modell. Software 22, 394-405.

Engman, E.T., Rogowski, A.S., 1974. Partial area model for storm flow synthesis. Water Resour. Res. 10, 464-472.

Evans, M.G., Burt, T.P., Holden, J., Adamson, J.K., 1999. Runoff generation and water table fluctuations in blanket peat: Evidence from UK data spanning the dry summer of 1995. J. Hydrol. 221, 141-160.

Fenicia, F., Savenije, H.H.G., Matgen, P., Pfister, L., 2007. A comparison of alternative multiobjective calibration strategies for hydrological modeling. Water Resour. Res. 43, W03434.

Fenicia, F., Solomatine, D.P., Savenije, H.H.G., Hoffmann, L., 2006. An approach to multi-criteria calibration of hydrologic models and their mixtures. In Geophysical Research Abstracts, p. 06834. SRef-ID: 1607-7962/gra/EGU06-A06834.

Gironás, J., Niemann, J.D., Roesner, L.A., Rodriguez, F., Andrieu, H., 2009. A morphoclimatic instantaneous unit hydrograph model for urban catchments based on the kinematic wave approximation. J. Hydrol. 377, 317-334

Göbel, P., Stubbe, H., Weinert, M., Zimmermann, J., Fach, S., Dierkes, C., Kories, H., Messer, J., Mertsch, V., Geiger, W.F., Coldewey, W.G., 2004. Near-natural stormwater management and its effects on the water budget and groundwater surface in urban areas taking account of the hydrogeological conditions. J. Hydrol. 299, 267-283.

Gupta, K., Saul, A.J., 1996. Specific relationships for the first flush load in combined sewer flows. Water Res. 30, 1244-1252.

Hernebring, C., Jönsson, L.E., Thorén, U.B., Moller, A., 2002. Dynamic online sewer modelling in Helsingborg. Water Sci. Technol. 45, 429-436.

Hingray, B., Picouet, C., Musy, A., 2009. Hydrologie 2: Une science pour l'ingénieur. Science et ingénierie de l'environnement, Presses Polytechniques et Universitaires Romandes, Lausanne, Switzerland.

Horton, R.E., 1940. An approach towards a physical interpretation of infiltration capacity. Soil Sci. Soc. Am. Proc. 5, 399-417.

Huff, F.A., Vogel, J.L., 1978. Urban, topographic and diurnal effects on rainfall in the St. Louis region. J. Appl. Meteorol. 17, 565-577.

Jacobson, C.R., 2011. Identification and quantification of the hydrological impacts of imperviousness in urban catchments: A review. J. Environ. Manage. 92, 1438-1448.

Jeanbourquin, D., Sage, D., Nguyen, L.S., Schaeli, B., Kayal, S., Barry, D.A., Rossi, L., 2011. Flow measurements in sewers based on image analysis: Automatic flow velocity algorithm. Water Sci. Technol. 64, 1108-1114.

Jordan, F., 2010. Modélisation du réseau d'assainissement: Outil de diagnostic et de planification en ville de Lausanne. GWA. Gas, Wasser, Abwasser 90, 199-208. ISSN: 1018-760X.
Karpf, C., Krebs, P., 2011. Quantification of groundwater infiltration and surface water inflows in urban sewer networks based on a multiple model approach. Water Res. 45, 3129-3136.

Kelman, J., 1980. A stochastic model for daily streamflow. J. Hydrol. 47, 235-249.

Kieffer, A., Bois, P., 2001. Topographic effects on statistical characteristics of heavy rainfall and mapping in the French Alps. J. Appl. Meteorol. 40, 720-740.

Kirkby, M., 1988. Hillslope runoff processes and models. J. Hydrol. 100, 315-339.

Lee, J.H., Bang, K.W., 2000. Characterization of urban stormwater runoff. Water Res. 34, 1773-1780.

Leon, A.S., Nania, L.S., V.S., 2010. Discussion of “ Potential Dangers of Simplifying Combined Sewer Hydrologic/ Hydraulic Models” by J.P. Cantone, A.R. Schmidt, J. Hydrol. Eng. 15, 587.

Martínez-Mena, M., Albaladejo, J., Castillo, V.M., 1998. Factors influencing surface runoff generation in a Mediterranean semi-arid environment: Chicamo watershed, SE Spain. Hydrol. Processes 12, 741-754.

Musy, A., 2005. Hydrologie generale. http://echo2.epfl.ch/e-drologie, (accessed 01).

Musy, A., Higy, C., 2010. Hydrology: A Science of Nature. CRC Press, ISBN: 9781578087099.

Nachabe, M.H., Illangasekare, T.H., Morel-Seytoux, H.J., Ahuja, L.R., Ruan, H., 1997. Infiltration over heterogenous watershed: Influence of rain excess. J. Hydrol. Eng. 2, 140-143.

Nash, J.E., Sutcliffe, J.V., 1970. River flow forecasting through conceptual models. Part I - A discussion of principles. J. Hydrol. 10, 282-290.

Nguyen, L.S., Schaeli, B., Sage, D., Kayal, S., Jeanbourquin, D., Barry, D.A., Rossi, L. 2009. Vision-based system for the control and measurement of wastewater flow rate in sewer systems. Water Sci. Technol. 60, 2281-2289.

Nicótina, L., Tarboton, D.G., Tesfa, T.K., Rinaldo, A., 2011. Hydrologic controls on equilibrium soil depths. Water Resour. Res. 47, W04517.

Perrin, C., Michel, C., Andréassian, V., 2001. Does a large number of parameters enhance model performance? Comparative assessment of common catchment model structures on 429 catchments. J. Hydrol. 242, 275-301.

Puente, C.E., Bierkens, M.F.P., DiazGranados, M.A., Dik, P.E., Lopez, D.E., 1993 Practical use of analytically derived runoff models based on rainfall point processes. Water Resour. Res. 29, 3551-3560.

Quinn, P., Beven, K.J., Chevallier, P., Planchon, O., 1991. The prediction of hillslope flow paths for distributed hydrological modelling using digital terrain models. Hydrol. Processes 5, 59-79.

Raghunath, H.M., 2006. Hydrology: Principles, Analysis and Design. New Age International Pvt. Ltd., Publishers, ISBN : 8122418255

Ravi, V., Williams, J.R., 1998. Estimation of infiltration rate in the vadose zone: Compilation of simple mathematical models. Technical Report. USEPA, EPA/ 600/R-97-128a. Washington, DC, USA.

Reusser, D.E., Blume, T., Schaefli, B., Zehe, E., 2008. Analysing the temporal dynamics of model performance for hydrological models. Hydrol. Earth Syst. Sci. 5, 31693211.

Rieckermann, J., Anta, J., Scheidegger, A., Ort, C., 2011. Assessing wastewater micropollutant loads with approximate bayesian computations. Environ. Sci. Technol. 45, 4399-4406.

Rinaldo, A., Botter, G., Bertuzzo, E., Uccelli, A., Settin, T., Marani, M., 2006. Transport at basin scales: 1 . Theoretical framework. Hydrol. Earth Syst. Sci. 10, 19-29.

Rodriguez, F., Andrieu, H., Creutin, J.D., 2003. Surface runoff in urban catchments: Morphological identification of unit hydrographs from urban databanks. J Hydrol. 283, 146-168.

Rodriguez, F., Cudennec, C., Andrieu, H., 2005. Application of morphological approaches to determine unit hydrographs of urban catchments. Hydrol. Processes 19, 1021-1035.

Rodrìguez-Iturbe, I., Porporato, A., 2005. Ecohydrology of Water-Controlled Ecosystems. Cambridge University Press.

Rodriguez-Iturbe, I., Valdes, J., 1979. The geomorphologic structure of hydrologic response. Water Resour. Res. 15, 1409-1420.

Rossi, L., Loizeau, J., Chèvre, N., Kadi, F., 2008. Influence des rejets urbains de temps pluie sur un littoral: exemple de la baie de Vidy, Lausanne. Technical Report. Ville de Lausanne.

Schaefli, B., Gupta, H.V., 2007. Do Nash values have value? Hydrol. Processes 21, 2075-2080.

Schaefli, B., Hingray, B., Niggli, M., Musy, A., 2005. A conceptual glacio-hydrological model for high mountainous catchments. Hydrol. Earth Syst. Sci. Discuss. 2, 73 117.

Seibert, J., 2000. Multi-criteria calibration of a conceptual runoff model using a genetic algorithm. Hydrol. Earth Syst. Sci. 4, 215-224.

Shaw, E.M., 1994. Hydrology in Practice. Spons Architecture Price Book.

Singh, V.P., Woolhiser, D.A., 2002. Mathematical modeling of watershed hydrology. J. Hydrol. Eng. 7, 270-292.

Thomet, M., 2010. Transport models at basin scale: Theoretical development and application to herbicides. Master's thesis ECHO-EPFL.

Todini, E., 1988. Rainfall-runoff modeling - past, present and future. J. Hydrol. 100, 341-352.

Wisner, P.E., Clarke, W.G., Roake, A.F., 1981. Studies for abatement of pollution from Combined Sewer Overflows in Canada. J. Hydrol. 51, 329-338.

Yadav, M., Wagener, T., Gupta, H., 2007. Regionalization of constraints on expected watershed response behavior for improved predictions in ungauged basins Adv. Water Resour. 30, 1756-1774.

Zoppou, C., 2001. Review of urban storm water models. Environ. Modell. Software $16,195-231$. 